\title{
Effects of anti-insulin antibody on insulin binding to liver membranes: evidence against antibody-induced enhancement of insulin binding to the insulin receptor
}

\author{
K. Komori, H. Nakayama, S. Aoki, Y.Kuroda, S. Tsushima and S. Nakagawa \\ Second Department of Internal Medicine, Hokkaido University School of Medicine, Sapporo, Japan
}

Summary. In the presence of anti-insulin antibody, 2- to 3-fold enhancement of ${ }^{125} \mathrm{I}$-insulin binding to liver membranes was observed when binding was estimated by the radioactivity of ${ }^{125} \mathrm{I}$-insulin bound to the membrane pellets. However, after ${ }^{125}$ I-insulin was covalently cross-linked to liver membranes using disuccinimidyl suberate in the presence of anti-insulin antibody, sodium dodecyl sulfate-polyacrylamide gel electrophoresis and autoradiography showed that ${ }^{125}$ I-insulin bound to the $\alpha$-subunit of the insulin receptor was inhibited by antiinsulin antibody in an dose-dependent manner. More importantly, at an anti-insulin antibody dilution range between 1:50 and 1:5,000, sodium dodecyl sulfate-polyacrylamide gel electrophoresis revealed two ${ }^{125}$ I-labelled bands of mol wt 62,000 and 27,000, while only one band of mol wt 130,000 was revealed in the absence of anti-insulin antibody. These $\mathrm{Mr}=62,000$ and $\mathrm{Mr}=27,000$ bands were found to be the heavy and the light chain of anti-insulin IgG molecules respectively. Pepsin digested anti-insulin serum had only an in- hibitory effect on ${ }^{125}$ I-insulin binding to liver membranes. Non-immunized guinea pig serum or IgG completely abolished the enhanced effect of anti-insulin antibody. Further, this enhanced effect was inhibited by Fc fragment-specific anti-IgG serum or H\&L-chain-specific anti-IgG serum in a dosedependent manner. Protein A also inhibited the effect of antiinsulin antibody. In IM-9 lymphocytes and human red blood cell ghosts, which have no Fc $\gamma$ receptors, enhancement of insulin binding was not observed in the presence of anti-insulin antibody. These data suggest that anti-insulin antibody-induced enhancement of insulin binding to liver membranes is not due to the enhanced binding to the insulin receptor itself but probably due to the binding of insulin-anti-insulin antibody complex to the Fc $\gamma$ receptor.

Key words: Anti-insulin antibody, insulin receptor, insulin binding, cross-linking, disuccinimidyl suberate, Fc $\gamma$ receptor, liver membrane.
It is reported that anti-insulin antibody(AIAB) at low concentrations induced cross-linking or aggregation of insulin-receptor complex and enhances the biological activity of bound insulin [1]. Shechter et al. [2] demonstrated that AIAB at optimal concentrations markedly increased ${ }^{125} \mathrm{I}$-insulin binding to liver membranes and 3T3-C2 fibroblasts but not to adypocyte membranes. They suggested that AIAB caused aggregation of the insulin-receptor complex on liver membranes and increased the affinity of the insulin receptor. They also suggested that the inability of AIAB to increase the insulin binding to adypocyte membranes was due to the differences in structural organization of the insulin receptor on adypocytes and liver membranes [3]. Recently, Lyen et al. [4] also reported AIAB-induced enhancement of insulin binding to liver membranes and demonstrated AIAB-induced aggregation of ferritin-insulin-occupied receptor using electron microscopy.

To investigate whether AIAB trully enhances the insulin binding to the insulin receptor itself, we used the methods of chemical cross-linking and sodium dodecyl sulfate-polyacrylamide gel electrophoresis (SDSPAGE) followed by autoradiography [5].

\section{Materials and methods}

\section{Materials}

Monocomponent porcine insulin was purchased from Novo Inc., Copenhagen, Denmark. ${ }^{125} \mathrm{I}$-porcine insulin $(160-220 \mu \mathrm{Ci} / \mu \mathrm{g})$ was purchased from Dainabot Co., Ltd. Tokyo, Japan. Most of the iodine atoms were attached to the tyrosine in A 14 position and a small quantity of them were in A 19 position. Disuccinimidyl suberate, pepsin, and protein A were purchased from Sigma Chemical Co., St Louis, Mo, USA. H\&L-chain-specific goat anti-guinea pig IgG serum and Fc fragment-specific anti-IgG serum were purchased from Cappel Laboratories Inc., Cochranville, Pa, USA. Anti-insulin antiserum was obtained by immunizing guinea pig with monocomponent porcine insulin.

\section{Methods}

Membrane and cell preparations. Liver plasma membranes were prepared from male Wister rats $(200-250 \mathrm{~g})$ by the two-phase polymer 


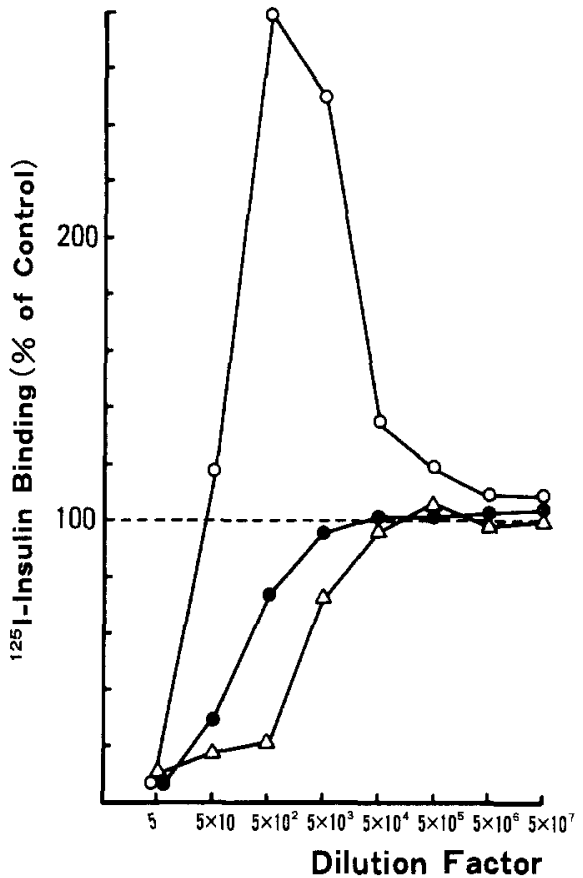

Fig. 1. The effects of anti-insulin antibody (AIAB) on ${ }^{125} \mathrm{I}$-insulin binding to liver membranes $(O), \operatorname{HRBC}$ ghosts $(\triangle)$, and IM-9 cells (O). Liver membranes $(100 \mu \mathrm{g} / \mathrm{ml})$, HRBC ghosts $(2 \mathrm{mg} / \mathrm{ml})$ or IM-9 cells $\left(10^{6} / \mathrm{ml}\right)$ were incubated with ${ }^{125} \mathrm{I}$-insulin $(0.2 \mathrm{ng} / \mathrm{ml})$ in the presence of variously diluted AIAB. Results were expressed as a percent of control (100) in the presence of non-immunized guinea pig serum. Each point is the mean of triplicate determinations

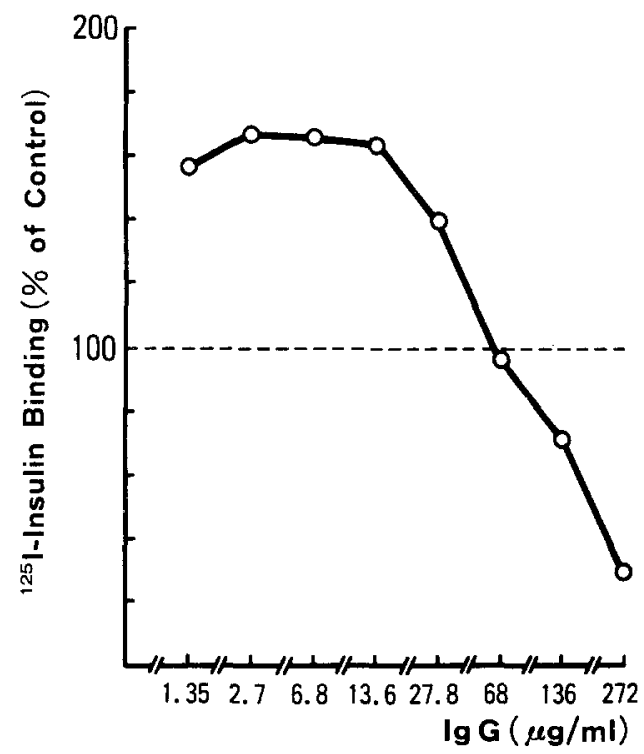

Fig. 2. The effect of purified $\mathrm{IgG}$ from anti-insulin antiserum on ${ }^{125} \mathrm{I}-$ insulin binding to liver membranes. Liver membranes $(100 \mu \mathrm{g} / \mathrm{ml})$ were incubated with ${ }^{125} \mathrm{I}$-insulin $(0.2 \mathrm{ng} / \mathrm{ml})$ in the presence of various concentrations of anti-insulin IgG. Results were expressed as a percent of control (100) in the absence of anti-insulin IgG. Each point is the mean of triplicate determinations

method described by Lesko et al. [6]. Human red blood cell (HRBC) ghost membranes were prepared from a normal volunteer according to the method of Dodge et al. [7]. IM-9 lymphocytes were grown at $37^{\circ} \mathrm{C}$ in RPMI 1640 medium containing $25 \mathrm{mmol} / 1$ Hepes base at pH 7.4 and $10 \%$ fetal calf serum. Cells in late $\log$ phase of growth were harvested by centrifugation at $600 \mathrm{~g}$ for $10 \mathrm{~min}$ before incubation.
Preparation of $\operatorname{IgG}$. IgG was prepared from anti-insulin guinea pig serum or non-immunized guinea pig serum by ammonium sulfate precipitation and DEAE-cellulose column chromatography [8].

Pepsin digestion of anti-insulin serum. Anti-insulin guinea pig serum was directly digested with pepsin for $18 \mathrm{~h}$ at $37^{\circ} \mathrm{C}$ according to the method described by Sire et al. [9]. Digested serum was dialysed against phosphate-buffered saline $\mathrm{pH} 7.4$ for $48 \mathrm{~h}$ and finally concentrated to the initial volume by ultrafiltration membrane, Centriflo CF 25 (Amicon Co., Danvers, Mass, USA).

Insulin binding studies. Insulin binding to liver membranes, HRBC ghosts and IM- 9 cells was conducted in $100 \mathrm{mmol} / 1$ Hepes buffer, ph 7.8 , containing $10 \mathrm{mmol} / 1 \mathrm{MgCl}_{2}, 2 \mathrm{mmol} / 1$ EDTA, $10 \mathrm{mmol} / 1$ Glucose, $10 \mathrm{mmol} / 1 \mathrm{CaCl}_{2}, 50 \mathrm{mmol} / 1 \mathrm{NaCl}, 5 \mathrm{mmol} / 1 \mathrm{KCl}$ and $1 \%$ BSA. Insulin binding studies were performed for $24 \mathrm{~h}$ at $4{ }^{\circ} \mathrm{C}$ by incubating either liver membranes $(100 \mu \mathrm{g} / \mathrm{ml}), \mathrm{HRBC}$ ghosts $(2 \mathrm{mg} / \mathrm{ml})$ or IM-9 cells $\left(10^{6} / \mathrm{ml}\right)$ with ${ }^{125} \mathrm{I}$-insulin $(0.2 \mathrm{ng} / \mathrm{ml})$ in the presence or absence of variously diluted AIAB.

In some experiments, purified $\operatorname{IgG}$ from anti-insulin serum was added. For experiments in which the effects of non-immunized guinea pig serum, $\mathrm{IgG}$, anti-IgG sera or protein $A$ were assessed, these materials were incubated with ${ }^{125} \mathrm{I}$-insulin and AIAB simultaneously. Bound hormone was separated from unbound hormone by centrifugation $(10,000 \mathrm{~g}$ for liver and HRBC ghost membranes and $600 \mathrm{~g}$ for IM-9 celis). Pellets were washed three times with assay buffer. Finally, ${ }^{125} \mathrm{I}$-insulin binding was determined by the radioactivity in the pellets. Non-specific binding in the presence of $10^{5} \mathrm{ng} / \mathrm{ml}$ insulin was determined and subtracted from total binding to yield specific binding. Non-specific binding was less than $20 \%$ of the total amount of bound hormone and was not significantly altered by AIAB. In these conditions, ${ }^{125} \mathrm{I}$-insulin degradation was less than $5 \%$ of the total ${ }^{125} \mathrm{I}$-insulin added and was not altered by AIAB as measured by the trichloroacetic acid precipitation method [10].

Cross-linking, gel electrophoresis and autoradiography. Liver membranes $(400 \mu \mathrm{g} / \mathrm{ml})$, HRBC ghosts $(2 \mathrm{mg} / \mathrm{ml})$ or IM- 9 cells $\left(10^{6} / \mathrm{ml}\right)$ were incubated for $24 \mathrm{~h}$ at $4{ }^{\circ} \mathrm{C}$ with ${ }^{125} \mathrm{I}$-insulin $(10 \mathrm{ng} / \mathrm{ml})$ in the presence or absence of various concentrations of AIAB. The incubation mixture was cooled to $0^{\circ} \mathrm{C}$ and diluted 3 -fold with assay buffer without BSA, and then centrifuged at $4^{\circ} \mathrm{C}$. After washing with the same buffer twice, the membranes or cell pellets were resuspended in the same buffer and freshly prepared disuccinimidyl suberate dissolved in dimethyl sulfoxide was added to a final concentration of $0.03 \mathrm{mmol} / 1$ [11]. After $15 \mathrm{~min}$, the reaction was quenched by addition of 5 volumes of ice-cold $10 \mathrm{mmol} / 1$ Tris, $1 \mathrm{mmol} / 1$ EDTA, $\mathrm{pH} 7.4$. This mixture was centrifuged and washed once, then boiled for 3 min in Laemmli's sample buffer [12] in the presence of $100 \mathrm{mmol} / 1$ dithiothreitol. ${ }^{125}$ I-insulin was also covalently cross-linked to AIAB after incubation for $24 \mathrm{~h}$ at $4^{\circ} \mathrm{C}$ without liver membranes and a portion of the mixture was added to the equal volume of twice concentrated sample buffer and then boiled. The discontinuous buffer system described by Laemmli [12] was used for analysis of the samples by SDS-PAGE. Separating gels contained $7.5 \%$ polyacrylamide. The gels were stained for $2 \mathrm{~h}$ in $0.025 \%$ Coomassie Blue $\mathrm{R}$ dissolved in $50 \%$ methanol, $10 \%$ acetic acid and were destained in 25\% methanol, $7 \%$ acetic acid. The dried gels were autoradiographed with Fuji X-ray film (Fiji Photo Film Co., Ltd. Tokyo, Japan) for $24-72 \mathrm{~h}$ at $-80^{\circ} \mathrm{C}$. As the standard of the mol wt, bovine plasma $\alpha_{2}$-macroglobulin (reduced, 170,000), rabbit muscle phosphorylase b $(97,400)$, bovine liver glutamate dehydrogenase $(36,500)$, and soybean trypsin inhibitor $(20,100)$ were used.

\section{Results}

The effects of various concentrations of AIAB on insulin binding to liver membranes, HRBC ghosts and IM-9 cells are shown in Figure 1. In liver membranes, ${ }^{125} \mathrm{I}$-insulin binding was markedly inhibited by AIAB at a final 


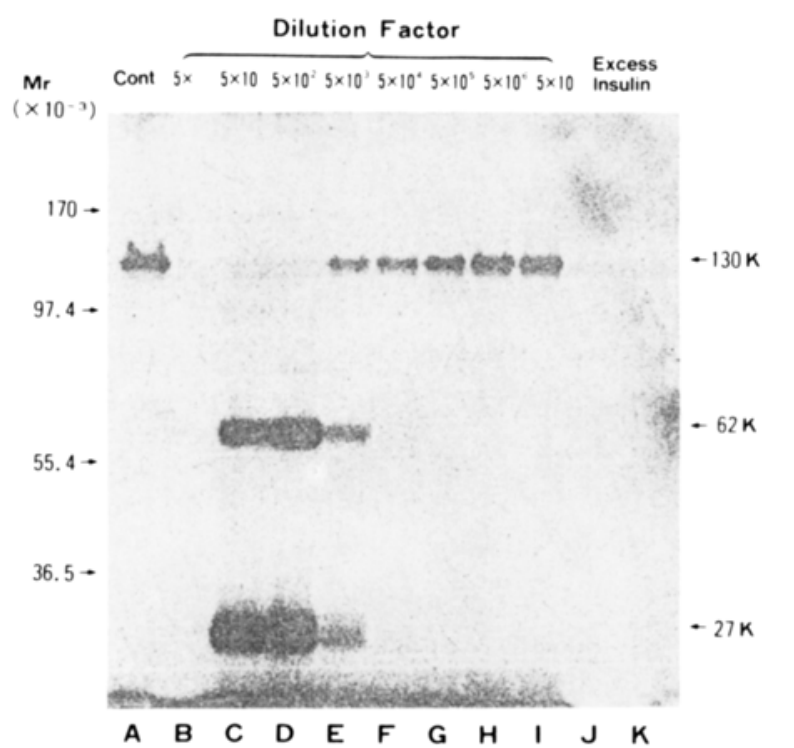

Fig. 3. Electrophoretic analysis of the effects of AIAB on ${ }^{125}$-insulin binding to liver membranes. ${ }^{125} \mathrm{I}$-insulin $(10 \mathrm{ng} / \mathrm{ml})$ and liver membranes $(400 \mu \mathrm{g} / \mathrm{ml})$ were incubated for $24 \mathrm{~h}$ at $4^{\circ} \mathrm{C}$ in the absence (A) and the presence of variously diluted AIAB ranging from $1: 5$ to $1: 5$ $\times 10^{7}$ (B to I). Excess amount of insulin $\left(10^{5} \mathrm{ng} / \mathrm{ml}\right)$ was added to the incubation mixture in the absence of $\operatorname{AIAB}(\mathbf{J})$, and in the presence of AIAB diluted by $1: 500(\mathrm{~K})$. After incubation, cross-linking and SDSPAGE followed by autoradiography were performed

dilution of $1: 5$, but about 3-fold stimulation was observed at an AIAB dilution of $1: 500$, followed by a return to the control level at lower concentrations. Enhancement of ${ }^{125} \mathrm{I}$-insulin binding to liver membranes was also achieved by purified $\mathrm{IgG}$ from anti-insulin antiserum (Fig. 2). On the other hand, ${ }^{125} \mathrm{I}$-insulin binding to HRBC ghosts and IM-9 cells was only inhibited by $A I A B$ in a dose-dependent manner (Fig. 1).

When ${ }^{125}$ I-insulin was covalently cross-linked to liver membranes by disuccinimidyl suberate, SDS-PAGE under reducing conditions revealed only one radioactive band of mol wt 130,000 in the presence of non-immunized guinea pig serum (Fig. 3, A). To assess the specificity of this band, ${ }^{125}$ I-insulin was cross-linked in the presence of exess amount of insulin. Insulin abolished the $\mathrm{Mr}=130,000$ band (Fig. 3, J), suggesting that this band corresponded to the $\alpha$-subunit of the insulin receptor [13, 14].

When ${ }^{125}$ I-insulin was cross-linked to liver membranes in the presence of various dilutions of AIAB, the $\mathrm{Mr}=130,000$ band was abolished in a dose-dependent manner (Fig. 3, B-I). More importantly, SDS-PAGE revealed two major bands of mol wt 62,000 and 27,000 at an $\mathrm{AIAB}$ dilution range between $1: 50$ and $1: 5,000$ (Fig. 3, C-E). These two bands were also abolished in the presence of exess amounts of insulin (Fig. 3, K). In HRBC ghosts or IM-9 cells, SDS-PAGE and radioautography showed that the $\mathrm{Mr}=130,000$ band was abolished by AIAB in a dose-dependent manner but no other bands were visible (data not shown).

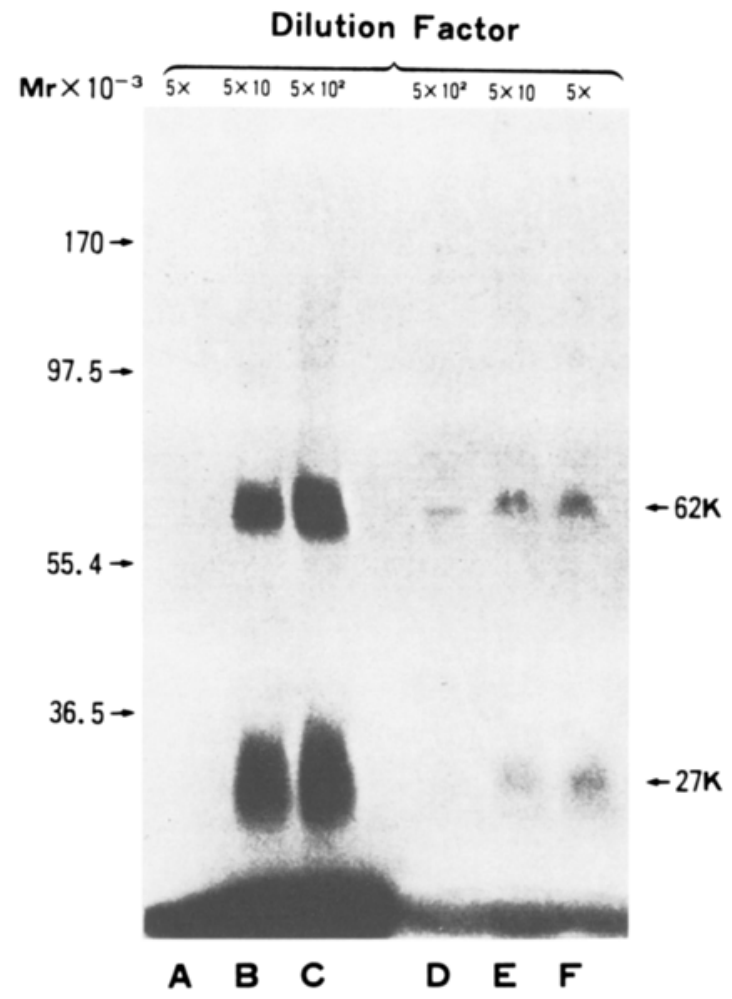

Fig.4. Electrophoretic analysis of the effects of AIAB on ${ }^{125}$ I-insulin binding to liver membranes. ${ }^{125} \mathrm{I}$-insulin $(10 \mathrm{ng} / \mathrm{ml})$ and AIAB (dilution range from $1: 5$ to $1: 500$ ) were incubated for $24 \mathrm{~h}$ at $4^{\circ} \mathrm{C}$ in the presence ( $A$ to $C$ ) and absence (D to $E$ ) of liver membranes. Crosslinking, SDS-PAGE and autoradiography were performed after incubation

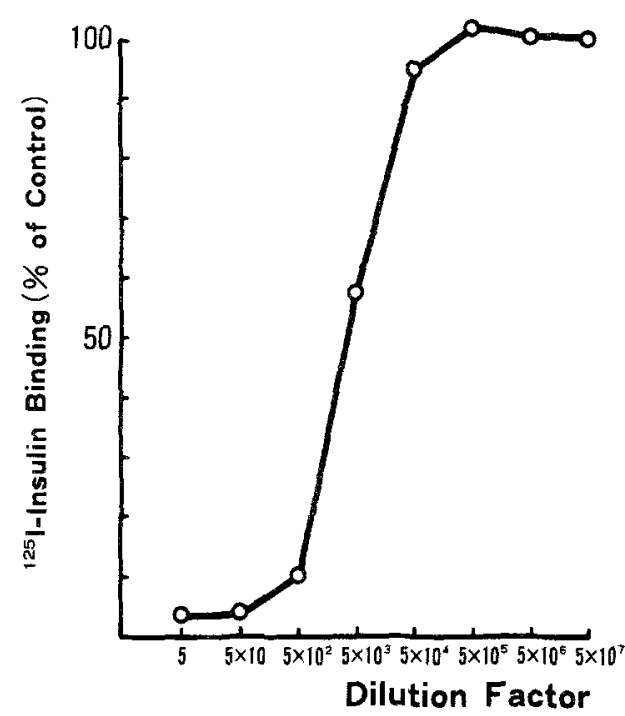

Fig.5. The effect of pepsin-digested anti-insulin serum on ${ }^{125} \mathrm{I}$-insulin binding to liver membranes. Liver membranes $(100 \mu \mathrm{g} / \mathrm{ml})$ were incubated with ${ }^{125} \mathrm{I}$-insulin $(0.2 \mathrm{ng} / \mathrm{ml})$ in the presence of variously diluted pepsin-digested anti-insulin serum. Results were expressed as a percent of control (100) in the presence of pepsin-digested non-immunized guinea-pig serum. Each point is the mean of triplicate determinations 


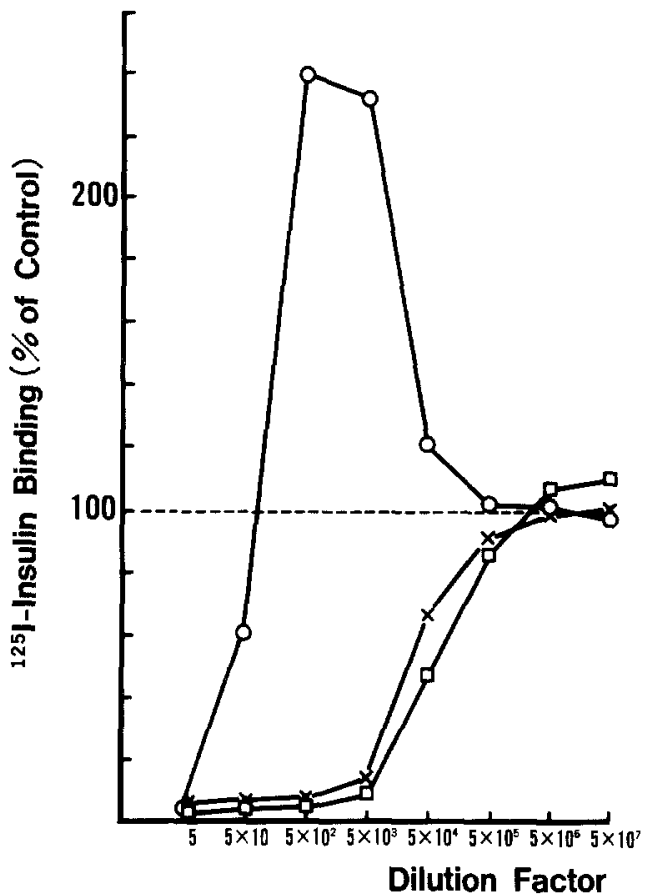

Fig. 6. Effects of non-immunized guinea pig serum and nonimmunized guinea pig IgG on $\mathrm{AIAB}$ enhanced ${ }^{125} \mathrm{I}$-insulin binding to liver membranes. Liver membranes $(100 \mu \mathrm{g} / \mathrm{ml}),{ }^{125} \mathrm{I}$-insulin $(0.2 \mathrm{ng} / \mathrm{ml})$ and variously diluted AIAB were incubated in the absence $(O)$ or presence of non-immunized guinea pig serum ( $\square$, final dilution, 1:5) or non-immunized guinea pig $\operatorname{IgG}$ ( $\mathrm{x}$, final concentration, $200 \mu \mathrm{g} / \mathrm{ml}$ ). As a control, liver membranes and ${ }^{125}$-I-insulin were incubated with non-immunized guinea pig serum. Results were expressed as a percent of control (100). Each point is the mean of triplicate determinations

To characterize these $\mathrm{Mr}=62,000$ and 27,000 bands, ${ }^{125}$ I-insulin was cross-linked to AIAB in the absence of liver membranes. SDS-PAGE of these preparations revealed the two same bands (Fig. 4, D-F) as were revealed in the presence of liver membranes (Fig. 4, A-C). This result indicates that $\mathrm{Mr}=62,000$ and 27,000 bands correspond to the heavy and the light chain of anti-insulin IgG molecule respectively.

There is a quantitative difference of the $62 \mathrm{~K}$ and the $27 \mathrm{~K}$ bands in lanes A to C and lanes D to F (Fig. 4), because the amounts of radioactivity applied to the lanes $\mathrm{D}$ to $\mathrm{F}$ (without liver membranes) is much smaller than that of the lanes $\mathrm{A}$ to $\mathrm{C}$ (with liver membranes).

We then examined the possibility that insulin-AIAB complex might bind to the Fcy receptor of the liver membrane [15]. Figure 5 shows the effect of pepsin-digested anti-insulin serum on ${ }^{125} \mathrm{I}$-insulin binding to liver membranes. ${ }^{125}$ I-insulin binding was inhibited by pepsin-digested serum in a dose dependent manner and ${ }^{125}$ I-insulin binding was no longer enhanced.

We further examined the effects of non-immunized guinea pig serum, non-immunized guinea pig $\mathrm{IgG}$, H\&L-chain-specific anti-IgG serum, Fc fragment-specific anti-IgG serum and protein A on AIAB-induced enhancement of ${ }^{125}$ I-insulin binding. When liver membranes, ${ }^{125} \mathrm{I}$-insulin and AIAB were incubated in the

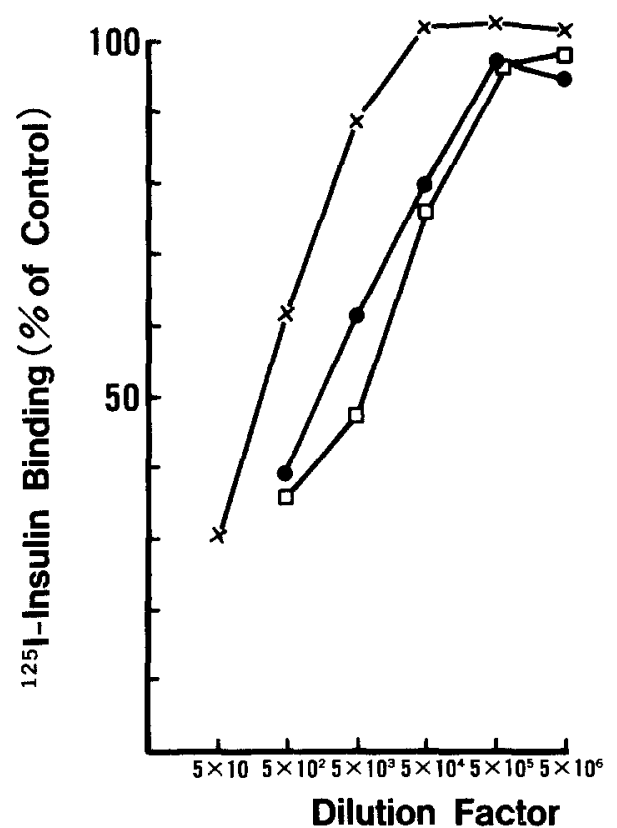

Fig. 7. Effects of non-immunized guinea pig $\operatorname{IgG}$ and anti-IgG sera on ${ }^{125}$ I-insulin binding to liver membranes in the presence of AIAB (final dilution, 1:500). Liver membranes $(100 \mu \mathrm{g} / \mathrm{ml}),{ }^{125} \mathrm{I}$-insulin $(0.2 \mathrm{ng} / \mathrm{ml})$ and AIAB $(1: 500)$ were incubated in the presence of variously diluted non-immunized $\operatorname{IgG}$ ( $\mathrm{x}$, original concentration, $20 \mathrm{mg}$ / $\mathrm{ml}), \mathrm{Fc}$ fragment-specific anti-IgG serum (O) or H\&L-chain-specific anti-IgG serum ( $\square$ ). As a control, liver membranes and ${ }^{125} \mathrm{I}$-insulin were incubated with AIAB alone (1:500). Results were expressed as a percent of control (100). Each point is the mean of triplicate determinations

presence of non-immunized guinea pig serum (final dilution, 1:5) or non-immunized guinea pig IgG (final concentration, $200 \mu \mathrm{g} / \mathrm{ml}$ ), the enhancing effect of AIAB was completely abolished (Fig. 6). The formation of the ${ }^{125}$ I-insulin-AIAB complex measured by dextrancoated charcoal method [16] was not significantly changed by the presence of non-immunized guinea pig serum or IgG (data not shown).

Figure 7 shows the effects of non-immunized IgG, Fc fragment-specific anti-IgG serum and H\&L-chainspecific anti-IgG serum on the enhancing effect of AIAB. ${ }^{125}$ I-insulin binding to liver membranes in the presence of AIAB (final dilution, 1:500) was inhibited by these materials in a dose-dependent manner. ${ }^{125} \mathrm{I}$-insulin bound to AIAB (final dilution, 1:500) was about $80 \%$ of the total ${ }^{125}$ I-insulin added and was not affected by IgG or anti-IgG sera (data not shown).

In the presence of protein $\mathrm{A}(20 \mu \mathrm{g} / \mathrm{ml}), \mathrm{H} \& \mathrm{~L}$-chainspecific anti-IgG serum (final dilution, 1:500) or $\mathrm{Fc}$ fragment-specific anti-IgG serum (final diluaiton 1: 500 ), enhancement of ${ }^{125} \mathrm{I}$-insulin binding by AIAB was abolished (Fig. $8 \mathrm{a}$ ), and after cross-linking, SDS-PAGE and autoradiography showed that the labelling of $\mathrm{Mr}=62,000$ and 27,000 bands were also inhibited by these materials (Fig. 8 b). 


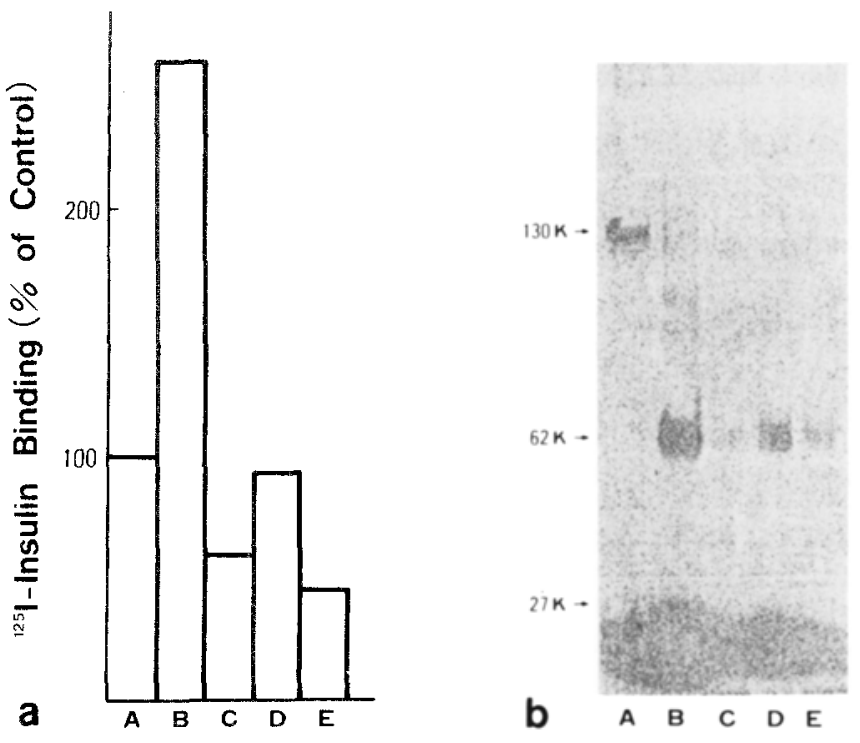

Fig. 8.a Effects of protein $A$, anti-Fc serum and H\&L-chain-specific anti-IgG serum on AIAB-induced enhancement of insulin binding. ${ }^{125} \mathrm{I}$-insulin $(0.2 \mathrm{ng} / \mathrm{ml})$, liver membranes $(100 \mu \mathrm{g} / \mathrm{ml})$ and AIAB (1: 500) were incubated for $24 \mathrm{~h}$ at $4{ }^{\circ} \mathrm{C}$ in the absence (B) or presence of protein A $(20 \mu \mathrm{g} / \mathrm{ml}, \mathrm{C})$, anti-Fc serum $(1: 500, \mathrm{D})$ and H\&L-chainspecific anti-IgG serum $(1: 500, E)$. Insulin binding was determined after centrifugation and expressed as a percent of control (100) in the absence of $\mathrm{AIAB}$ and any of those three materials described above (A). Each column shows the mean of duplicate determinations. b Electrophoretic analysis of the effects of protein A, anti-Fc serum and $\mathrm{H} \& \mathrm{~L}$-chain-specific anti-IgG serum on AIAB-induced enhancement of insulin binding. ${ }^{125} \mathrm{l}$-insulin $(10 \mathrm{ng} / \mathrm{ml})$, liver membrane $(400 \mu \mathrm{g} / \mathrm{ml})$ and $\operatorname{AIAB}(1: 500)$ were incubated for $24 \mathrm{~h}$ at $4^{\circ} \mathrm{C}$ in the absence (B) or presence of protein $A(20 \mu \mathrm{g} / \mathrm{ml}, C)$, anti-Fc serum (1: $500, D)$ and $H \& L$-chain-specific anti-IgG serum $(1: 500, E)$. As a control study, ${ }^{125}$ I-insulin and liver membrane were incubated without any other materials described above (A). Cross-linking, SDS PAGE and autoradiography were performed after incubation. Result corresponds to one representative experiment

\section{Discussion}

${ }^{125}$ I-insulin binding to liver membranes was enhanced by AIAB at optimal concentrations when it was estimated by the radioactivity in the membrane pellets. This agrees with the results of Shechter et al. [2]. However, using the methods of covalent cross-linking of ${ }^{125}$ I-insulin to the insulin receptor and AIAB, we clearly showed that ${ }^{125} \mathrm{I}$-insulin binding to the $\alpha$-subunit of the liver membrane insulin receptor was only inhibited by AIAB in a dose dependent manner. More importantly, SDSPAGE, under reducing conditions and autoradiography, revealed $\mathrm{Mr}=62,000$ and 27,000 bands at the concentrations of AIAB which markedly increased ${ }^{125} \mathrm{I}$-insulin binding to liver membranes. These two bands were found to correspond to the heavy and the light chain of anti-insulin IgG molecule respectively.

It is not likely that the association of insulin radioactivity to the light and heavy chain of the AIAB is an artifact of the cross-linking reaction because these two bands were not observed in IM-9 cells and RBC ghosts under the same experimental condition.
These results suggest that insulin-AIAB complex might bind to the liver membrane through the Fcy receptor (15). The following findings, although they provide indirect evidence, are in support of this hypothesis. First, pepsin digested AIAB, which seemed to be separated to $\left(\mathrm{Fab}^{\prime}\right)_{2}$ and $\mathrm{Fc}$ fragments of the $\mathrm{IgG}$ molecules [9], no longer enhanced the insulin binding. This result indicates that the Fc portion of anti-insulin IgG might play some role on the enhancement of insulin binding to liver membranes. Second, in IM-9 cells and HRBC ghosts, which have no Fcy receptor $[17,18]$, AIAB-induced enhancement of the insulin binding was not observed and SDS-PAGE did not reveal ${ }^{125}$ I-labelled heavy and light chains of $\mathrm{IgG}$ which were observed in liver membranes. Third, protein A, which binds to the Fc portion of the IgG molecule, inhibited the AIAB-induced enhancement of insulin binding and also inhibited the appearance of the heavy and the light chains in the autoradiography. Finally, non-immunized guinea pig serum or non-immunized guinea pig IgG completely abolished the enhancing effect of AIAB. This indicates that ${ }^{125}$ I-insulin-AIAB complex could no longer bind to the Fc $\gamma$ receptor because the Fc $\gamma$ receptors were occupied and saturated by excess non-immune IgG.

This possibility is supported by the finding that ${ }^{125} \mathrm{I}-$ insulin binding in the presence of $\operatorname{AIAB}(1: 500)$ was inhibited by non-immune IgG in a dose-dependent manner. Since ${ }^{125} \mathrm{I}$-insulin binding to AIAB was not affected by non-immune IgG or anti-IgG sera, it is not likely that the inhibition of the enhancing effect of AIAB is due to the inhibition of the formation of ${ }^{125}$ I-insulin-AIAB complex. Further, we confirmed that the inhibition of the enhancing effect of AIAB by protein A and antiIgG sera was well correlated to the decreased density of the $62 \mathrm{~K}$ and $27 \mathrm{~K}$ bands.

It seems that these anti-IgG sera competed for $\mathrm{Fc} \gamma$ receptors with ${ }^{125}$ I-insulin-AIAB complex as non-immune IgG. However, the reason is unclear why ${ }^{125} \mathrm{I}$-insulin binding in the presence of AIAB $(1: 500)$ was inhibited by these anti-IgG sera. If ${ }^{125}$ I-insulin-AIAB-anti-IgG antibody complex may be formed, it may bind to the Fc $\gamma$ receptor through the Fc portion of anti-IgG antibody. It is possible that the spacial configuration of the $\mathrm{Fc}$ portion of anti-IgG by combination to insulin-AIAB complex interfered with the binding of $\mathrm{Fc}$ portion to the Fc $\gamma$ receptor site as suggested by Khokher et al. [19]. SDS-PAGE and radioautography revealed no radioactive bands at an AIAB dilution of 1:5 (Fig. 3, B). In this condition, there was an excess of AIAB, and it is likely that $\mathrm{Fc} y$ receptors were saturated by free $\mathrm{AIAB}$ which had not bound to ${ }^{125}$ I-insulin.

We could not find the radioactive bands which might represent the ${ }^{125} \mathrm{I}$-insulin-AIAB-Fc $\gamma$ receptor complex in SDS-PAGE and autoradiography. There is no report up to date about the identification of the Fc $\gamma$ receptor by using the cross-linking method. It is possible that the cross-linking reagent could not get access to the reaction sites of both $\mathrm{AIAB}$ and the $\mathrm{Fc} \gamma$ receptor to 
which it might be bound. The reason for this, however, is not known, and further investigation is necessary.

In conclusion, our studies demonstrate that AIABinduced enhancement of insulin binding to liver membranes is not due to the increased binding to the insulin receptor, but probably due to the binding of the insulinAIAB complex to the Fcy receptor of the liver membrane. In the presence of AIAB, insulin binding studies estimated by the radioactivity in the membrane pellets do not accurately reflect the insulin binding to the insulin receptor itself. However, it is still possible that very low concentrations of $\mathrm{AIAB}$, at which insulin binding to the insulin receptor is not nearly inhibited, enhance the biological activity of coexisting insulin in intact cells as observed by Kahn et al. [1].

The evidence obtained for our hypothesis, however, is indirect because we could not demonstrate the crosslinking of the insulin-AIAB complex to the Fc $\gamma$ receptor.

\section{References}

1. Kahn CR, Baird KL, Jarrett DB, Flier JS (1978) Direct demonstration that receptor crosslinking or aggregation is important in insulin action. Proc Natl Acad Sci 75: 4209-4213

2. Shechter Y, Chang K, Jacobs S, Cuatrecasas P (1979) Modulation of binding and bioactivity of insulin by anti-insulin antibody: relation to possible role of receptor self-aggregation in hormone action. Proc Natl Acad Sci 76:2720-2724

3. Jarett L, Schweitzer JB, Smith RM (1980) Insulin receptors: differences in structural organization on adipocytes and liver plasma membranes. Science 210: 1127-1128

4. Lyen RK, Smith MR, Jarett L (1983) Differences in the ability of anti-insulin antibody to aggregate monomeric ferritin-insulin occupied receptor sites on liver and adipocyte plasma membranes. Diabetes 32: 648-653

5. Pilch FP, Czech MP (1979) Interaction of cross-linking agents with the insulin effector system of isolated fat cells. J Biol Chem 254: 3375-3381

6. Lesko L, Donlon M, Marinetti GV, Hare D (1973) A rapid method for the isolation of rat liver plasma membranes using an aqueous two-phase polymer system. Biochim Biophys Acta 311: 173-179
7. Dodge JT, Mitchel C, Hanahan DJ (1963) The preparation and chemical characteristics of hemoglobin-free ghosts of human erythrocytes. Arch Biochem Biophys 100: 119-130

8. Leslie RGQ, Cohen S (1970) Chemical properties of guinea pig immunoglobulins $\gamma_{1}, \mathrm{G}, \gamma_{2} \mathrm{G}$ and $\gamma \mathrm{M}$. Biochem $\mathrm{J} 120: 787-795$

9. Sire J, Kahn-Perles B, Colli A, Bourgois A (1980) Biochemical characterization of an $\mathrm{Fc}$ receptor of rabbit lymphocytes. Eur $\mathrm{J}$ Immunol 10: 116-121

10. Freychet P, Kahn CR, Roth J, Neville Jr DM (1972) Insulin interactions with liver plasma membranes. J Biol Chem 247: 3953-3961

11. Kasuga M, Van Obberghen E, Yamada KM, Harrison LC (1981) Auto-antibodies against the insulin receptor recognize the insulin binding subunits of an oligomeric receptor. Diabetes 30: 354-357

12. Laemmli UK (1970) Cleavage of structural proteins during the assembly of the head of bacteriophage T4. Nature 227:680-685

13. Massague J, Czech MP (1980) Multiple redox form of the insulin receptor in native liver membranes. Diabetes 29: 945-947

14. Massague J, Pilch PF, Czech MP (1980) Electrophoretic resolution of three major insulin receptor structures with unique subunit stoichiometries. Proc Natl Acad Sci 77: 7137-7141

15. Frommel D, Rachman F (1979) Receptor for the Fc portion of IgG on the hepatocyte. Ann Immunol 130 C: $553-560$

16. Herbert V, Lau KS, Gottlieb CW, Bleicher SJ (1965) Coated charcoal immunoassay of insulin. J Clin Endocrinol Metab 25: $1375-1384$

17. Aikawa T, Mitamura T, Tanimoto K, Horiuchi Y (1979) Detection of circulating immune complexes by using human red blood cells. J Lab Clin Med 94: 902-916

18. ATCC CCL 159 IM-9 (Lymphoblast, Immunoglobulin secreting, human) (1985) In: Hay R, Macy M, Corman-Weinblatt A, Chen TR, McClintock P (eds) American type culture collection catalogue of cell lines and hybridomas fifth edition, 1985. American Type Culture Collection, Rockville, Maryland, p 87

19. Khokher MA, Dandona P (1983) Insulin-like stimulatory effects of Fc fragments of human immunoglobulin $\mathrm{G}$ on rat adipocyte lipogenesis: Indirect evidence for $\mathrm{Fc}$ receptor on adipocytes. J Clin Endocrinol Metab. 56: 393-396

Received: 11 October 1985

and in revised form: 23 May 1986

Dr. K. Komori

Second Department of Internal Medicine

Hokkaido University School of Medicine

Kita 15, Nishi 7, Kita Ku

Sapporo, 060, Japan 